\title{
Monetary valuation of cardiovascular disease in Canada
}

\author{
Ehsan Latif * \\ Department of Economics, Thompson Rivers University, Canada
}

Received: 11 February 2012

Revised: 4 April 2012

Accepted: 15 April 2012

\begin{abstract}
The study estimated a well-being function to determine how much monetary value individuals assign for cardiovascular disease in Canada. The study found that the calculated compensating income variation is $\$ 33,701$, suggesting that an individual is required to be paid this amount to compensate for the loss in well-being due to cardiovascular disease. The study further shows that the compensating income variation is higher for women than for men. The study also finds that compensating income variation decreases with age.
\end{abstract}

Keywords: subjective well-being, monetary valuation, cardiovascular disease, Canada JEL Classification Codes: I18, I31

\section{Introduction}

Cardiovascular Disease (CVD) is the second leading cause of death in Canada. In 2007, CVD accounted for 64,480 or $28 \%$ of all deaths in Canada (Statistics Canada, 2010). In the same year (2007), about 1.3 million Canadians reported having heart disease diagnosed by a health professional. In 2005-2006, $19 \%$ of all hospitalizations were due to CVD, and this disease accounted for the highest proportion of days in hospital compared to other health problems. It is estimated that CVD costs amounted to $\$ 22.2$ billion in 2000 (Public Health Agency, 2009).

Though CVD has very high costs, to the best of the knowledge of this author, no study in Canada so far has examined how much monetary value individuals will attach to cardiovascular disease. ${ }^{1}$ Public sector plays a very significant role in Canadian health care system and in allocating resources for prevention and treatment of a particular

\footnotetext{
*E-mail: elatif@tru.ca.

Citation: Latif, E. (2012) Monetary valuation of cardiovascular disease in Canada, Economics and Business Letters, 1(1), 46-52.

${ }^{1}$ The author used search engines 'google scholar' and 'pubmed' to find whether there was any study done on monetary valuation of 'cardiovascular Disease' in Canada.
} 
disease, it is important that the government has information about the value individuals attach to that disease. This study utilized subjective well-being approach to estimate the additional income that an individual requires to be paid to compensate for the loss in well-being due to cardiovascular disease. The result of this study is expected to help Canadian health care authority while making decision about allocating resource in prevention and treatment of cardiovascular disease.

The well-being approach is built on recent developments of happiness research in economics (Clark et al. 2008; Frey and Sutzer, 2002). A number of studies have used a well-being approach for valuing public goods (Frey et al. 2009; Luechinger, 2009). In these studies, self-reported life satisfaction is regressed on the public good of interest, income, and other covariates. Using the coefficients for the public good and income, these studies calculated utility constant trade-off ratios between the public good and income. A few studies used this approach to estimate monetary values of health changes (Ferrer-i-Carbonell and Van Pragg, 2002; Groot and Maassen van den Brink, 2006). Groot and Maassen van den Brink (2006) focused on cardiovascular disease. Using longitudinal data from the British Household Panel Survey, Groot and Maassen van den Brink (2006) estimated the compensating income variation (CIV) of cardiovascular disease. They found that the CIVs of cardiovascular disease for men and women were $£ 49,594$ and $£ 17,503$ respectively. They also found that CIV decreased with age.

The paper is structured in the following way: Section 2 discusses data and methodology; Section 3 presents results of the study; Section 4 is the concluding section.

\section{Data and Methodology}

\subsection{Data $^{2}$}

The present study uses nationally representative longitudinal Canadian data from the National Population Health Survey (NPHS). The NPHS collects information related to the health of the Canadian population and related socio-demographic information. The NPHS started in 1994-1995 and is conducted every two years. In each cycle, a common set of health questions is asked to the respondents, and the questionnaire includes focus group content and supplements that change from cycle to cycle. The currently available data consist of the following seven cycles (interviews): 1994-1995, 1996-1997, 19981999, 2000-2001, 2002-2003, 2004-2005 and 2006-2007. This study restricts the sample to adults aged 25 and over, yielding 37,200 person-wave observations.

The dependent variable of this study is psychological well-being, which is measured using the following ordered responses: 1. so unhappy in life, 2. very unhappy, 3. somewhat unhappy, 4. somewhat happy, 5. happy in life. ${ }^{3}$ The variable of interest, 'Cardiovascular Disease,' is a dummy variable representing whether the individual has heart disease or not.

\footnotetext{
2 This section is based on NPHS documentation obtained from the Statistics Canada website at http://www.statcan.gc.ca/start-debut-eng.html

${ }^{3}$ The only available measure of life satisfaction in the National Population Health Survey (NPHS) is the variable 'Psychological Well-Being'. Life Satisfaction is considered to be a good measure of well-being for well-being approach since life satisfaction reflects individual's total or global well-being while other measures such as health satisfaction and self assessed health suggest domain specific well-being (Powdthavee and Bernard van den Berg, 2011).
} 
The NPHS contains information on the determinants of psychological well-being such as age, marital status, education, employment status, income, housing ownership, chronic conditions, and provinces. ${ }^{4}$ Age is a continuous variable and the regression also includes squared age to capture the non-linear impact of age on health. Marital status has three categories: single, married, and divorced/widowed; the base category is "single." The education level has four categories: less than secondary, secondary, other post-secondary, and college-university. The study uses "less than secondary" as the base. Employment status has four categories: employed, unemployed, not in labor force, and retired; the base category is "employed." The household income variable is also a continuous variable. The dummy variable "urban location" represents whether an individual lives in an urban area or not. The dummy variable "own house" represents whether the individual has owned a home or not.

\subsection{Methodology}

The well-being function is written as a function of income, health status, and other characteristics in the following form:

$$
W B_{i t}=w\left(Y_{i t}, H_{i t}, Z_{i t}\right)
$$

where $W B_{i t}$ denotes the well-being of individual $i$ at period $t, Y_{i t}$ is the household income, $H_{i t}$ denotes health status as reflected by the presence of a chronic condition, and $Z_{i t}$ is a vector of individual demographic and socio-economic variables such as age, marital status, education, employment status, and provinces of residence.

In equation (1), the relationship between well-being and income is expected to be positive, implying that an increase in income will enhance individual well-being. On the other hand, the presence of a chronic condition such as 'Cardiovascular Disease' is expected to reduce individual well-being.

The equation (1) can be used to obtain the money amount needed to make someone with 'Cardiovascular Disease' as well off as someone without this chronic condition. This monetary value, termed compensating income variation (CIV), is written as:

$$
\partial Y / \partial H=-\frac{\partial W / \partial H}{\partial W / \partial Y}
$$

The monetary valuation of 'Cardiovascular Disease' can be determined by estimating the empirical counterpart of equation (1) in the following form:

$$
W B_{i t}=\alpha^{\prime}+\beta_{1}^{\prime} Y_{i t}+\beta_{2}^{\prime} H_{i t}+\beta_{3}^{\prime} Z_{i t}+\mu_{i}+\varepsilon_{i t}
$$

where $\mu_{i}$ represents individual specific unobservable fixed effects and $\varepsilon_{i t}$ is a random error term. The term $\mu_{i}$ captures the influence of an individual's personality traits as well as other unobserved individual specific heterogeneity that are constant over time.

The well-being equation can be estimated using a fixed effect method, as this method factors out individual specific fixed effects from the equation and thus is expected to produce unbiased estimations.

\footnotetext{
${ }^{4}$ To select control variables, this study follows two other similar studies (Powdthavee and Bernard van den Berg, 2011; Groot and Maassen van den Brink, 2006). However, unlike the British Household Panel Survey (BHPS) used by the above mentioned two studies, the NPHS does not have extensive list of chronic condition variables. Furthermore, because of multicollinearity and very low frequency, the study could not use a number of chronic conditions as control variables.
} 


\section{Results}

Table 1 provides descriptive statistics showing comparison between male sample and female sample. The results of the fixed effect model are presented in Table 2. ${ }^{5}$ The results of the fixed effect regression show that the coefficient of 'Cardiovascular Disease' is negative and significant, suggesting that cardiovascular disease significantly reduces psychological well-being. Other results of the regression are as follows: household income has a significant positive impact on psychological well-being; happiness decreases with age but at a decreasing rate; being married has a significant positive effect on happiness, while being divorced reduces happiness; unemployed and individuals not in the labor force are less happy than employed individuals; retired people are happier than employed individuals; high blood pressure, cancer, and activity limitation significantly reduce psychological well-being.

Table 1. Descriptive Statistics

\begin{tabular}{|c|c|c|c|c|c|}
\hline Variable & Male & Female & Variable & Male & Female \\
\hline Age* & $\begin{array}{l}45.56 \\
(.155)\end{array}$ & $\begin{array}{l}46.99 \\
(.143)\end{array}$ & Cancer & $\begin{array}{c}.011 \\
(.001)\end{array}$ & $\begin{array}{l}.015 \\
(.001)\end{array}$ \\
\hline Single & $\begin{array}{l}.196 \\
(.004)\end{array}$ & $\begin{array}{l}.151 \\
(.003)\end{array}$ & Activity Limitation & $\begin{array}{l}.188 \\
(.004)\end{array}$ & $\begin{array}{l}.214 \\
(.003)\end{array}$ \\
\hline Married & $\begin{array}{l}.714 \\
(.005)\end{array}$ & $\begin{array}{l}.649 \\
(.004)\end{array}$ & Having Own House & $\begin{array}{l}.778 \\
(.005)\end{array}$ & $\begin{array}{l}.750 \\
(.004)\end{array}$ \\
\hline Divorced/Widowed & $\begin{array}{l}.089 \\
(.003)\end{array}$ & $\begin{array}{l}.198 \\
(.003)\end{array}$ & Living in Urban Location & $\begin{array}{l}.790 \\
(.004)\end{array}$ & $\begin{array}{c}.811 \\
(.003)\end{array}$ \\
\hline Less than Secondary & $\begin{array}{l}.149 \\
(.003)\end{array}$ & $\begin{array}{l}.154 \\
(.003)\end{array}$ & Living in Ontario & $\begin{array}{l}.389 \\
(.005)\end{array}$ & $\begin{array}{l}.363 \\
(.004)\end{array}$ \\
\hline Secondary Education & $\begin{array}{l}.139 \\
(.004)\end{array}$ & $\begin{array}{l}.151 \\
(.003)\end{array}$ & Living in Newfoundland & $\begin{array}{c}.017 \\
(.0007)\end{array}$ & $\begin{array}{c}.019 \\
(.0006)\end{array}$ \\
\hline Other Post-Secondary Ed. & $\begin{array}{l}.269 \\
(.005)\end{array}$ & $\begin{array}{l}.267 \\
(.004)\end{array}$ & Living in PEI & $\begin{array}{c}.005 \\
(.0003)\end{array}$ & $\begin{array}{c}.005 \\
(.0001)\end{array}$ \\
\hline College/University Education & $\begin{array}{l}.440 \\
(.005)\end{array}$ & $\begin{array}{l}.425 \\
(.004)\end{array}$ & Living in Nova Scotia & $\begin{array}{l}.036 \\
(.001)\end{array}$ & $\begin{array}{l}.035 \\
(.001)\end{array}$ \\
\hline Employed & $\begin{array}{l}, 712 \\
(.08)\end{array}$ & $\begin{array}{l}.511 \\
(.023)\end{array}$ & Living in New Brunswick & $\begin{array}{c}.026 \\
(.001)\end{array}$ & $\begin{array}{c}.028 \\
(.0008)\end{array}$ \\
\hline Cardiovascular Disease & $\begin{array}{c}.046 \\
(.002)\end{array}$ & $\begin{array}{c}.036 \\
(.001)\end{array}$ & Living in Quebec & $\begin{array}{c}.251 \\
(.005)\end{array}$ & $\begin{array}{l}.262 \\
(.004)\end{array}$ \\
\hline Arthritis & $\begin{array}{l}.111 \\
(.003)\end{array}$ & $\begin{array}{c}.184 \\
(.003)\end{array}$ & Living in Manitoba & $\begin{array}{l}.033 \\
(.001)\end{array}$ & $\begin{array}{l}.035 \\
(.001)\end{array}$ \\
\hline High Blood Pressure & $\begin{array}{l}.125 \\
(.004)\end{array}$ & $\begin{array}{c}.160 \\
(.003)\end{array}$ & Living in Saskatchewan & $\begin{array}{c}.030 \\
(.001)\end{array}$ & $\begin{array}{c}.029 \\
(.0009)\end{array}$ \\
\hline Bronchitis & $\begin{array}{l}.017 \\
(.001)\end{array}$ & $\begin{array}{l}.027 \\
(.001)\end{array}$ & Living in Alberta & $\begin{array}{l}.088 \\
(.002)\end{array}$ & $\begin{array}{l}.100 \\
(.002)\end{array}$ \\
\hline Diabetes & $\begin{array}{l}.034 \\
(.002) \\
\end{array}$ & $\begin{array}{l}.029 \\
(.001) \\
\end{array}$ & Living in British Columbia & $\begin{array}{l}.119 \\
(.003) \\
\end{array}$ & $\begin{array}{l}.117 \\
(.003)\end{array}$ \\
\hline
\end{tabular}

Standard errors are shown in the parentheses. *Figures for 'Age' show mean values while all other figures represent proportion.

The coefficients of household income and cardiovascular disease are used to estimate the compensating variation for cardiovascular disease. The coefficient of household income suggests that an additional $\$ 10,000$ in annual income increases psychological well-being by .0181 units. On the other hand, the coefficient of 'Cardiovascular Disease' implies that this disease reduces well-being by .061 units on a 1-5 scale. The calculated Compensating Income Variation is \$33,701, suggesting that an individual is required to be paid this amount to compensate for well-being loss due to cardiovascular disease.

\footnotetext{
${ }^{5}$ The study conducted both pooled OLS and fixed effect regressions for the overall sample. The result of the $\mathrm{F}$ test confirmed the presence of individual specific unobserved heterogeneity and thus the fixed effect model is preferred over the pooled OLS model.
} 
Table 2. Fixed Effect Regression results of Well-Being

\begin{tabular}{|c|c|c|c|}
\hline Variable & Coefficient & Variable & Coefficien \\
\hline Age & $\begin{array}{c}.019 * * \\
(.009)\end{array}$ & $\begin{array}{l}\text { Education: Base }=\text { Less than } \\
\text { Secondary }\end{array}$ & \\
\hline Squared Age & $\begin{array}{l}.00008 * \\
(.00002)\end{array}$ & Secondary Education & $\begin{array}{l}-.051 \\
(.041)\end{array}$ \\
\hline Marital Status: Base $=$ Single & & Other Post-Secondary Education & $\begin{array}{l}-.022 \\
(.038)\end{array}$ \\
\hline Married & $\begin{array}{l}.051 * \\
(.013)\end{array}$ & College/University Education & $\begin{array}{l}-.004 \\
(.035)\end{array}$ \\
\hline Divorced/Widowed & $\begin{array}{l}-.064 * \\
(.017)\end{array}$ & & \\
\hline Work Status: Base = Employed & & Province: Base $=$ Ontario & \\
\hline Unemployed & $\begin{array}{l}-.051^{*} \\
(.013)\end{array}$ & Newfoundland & $\begin{array}{l}-.022 \\
(.047)\end{array}$ \\
\hline Not in Labor Force & $\begin{array}{l}-.047 * \\
(.009)\end{array}$ & PEI & $\begin{array}{l}-.050 \\
(.057)\end{array}$ \\
\hline Retired & $\begin{array}{l}.058^{*} \\
(.010)\end{array}$ & Nova Scotia & $\begin{array}{l}-.050 \\
(.048)\end{array}$ \\
\hline House Hold Income/10,000 & $\begin{array}{l}.0181 * * \\
(.0084)\end{array}$ & New Brunswick & $\begin{array}{l}. .070) \\
-.007 \\
(.047)\end{array}$ \\
\hline Cardiovascular Disease & $\begin{array}{l}-.061 * \\
(.015)\end{array}$ & Quebec & $\begin{array}{l}-.046 \\
(.048)\end{array}$ \\
\hline Arthritis & $\begin{array}{l}. .006 \\
(.007)\end{array}$ & Manitoba & $\begin{array}{l}-.020 \\
(.051)\end{array}$ \\
\hline High Blood Pressure & $\begin{array}{c}-.019 * * \\
(.010)\end{array}$ & Saskatchewan & $\begin{array}{l}-.080 \\
(.050)\end{array}$ \\
\hline Bronchitis & $\begin{array}{l}-.028 \\
(.019)\end{array}$ & Alberta & $\begin{array}{l}-.015 \\
(.035)\end{array}$ \\
\hline Diabetes & $\begin{array}{c}.016 \\
(.017)\end{array}$ & British Columbia & $\begin{array}{c}.037 \\
(.044)\end{array}$ \\
\hline Cancer & $\begin{array}{c}-.048 * * \\
(.020)\end{array}$ & & \\
\hline Activity Limitation & $\begin{array}{l}-.074 * \\
(.007)\end{array}$ & Constant & $\begin{array}{c}4.94 \\
(.417)\end{array}$ \\
\hline Own House & $\begin{array}{l}-.003 \\
(.008)\end{array}$ & & \\
\hline Urban Location & $\begin{array}{c}.006 \\
(.009)\end{array}$ & & \\
\hline
\end{tabular}

Significance levels: $* 0.01, * * 0.05$. Standard errors, clustered by individual, are shown in the parentheses.

Table 3. Results of Well-Being Equation by Gender and Age

\begin{tabular}{lcccc}
\hline \hline Variable & Male & Female & Age<55 & Age $\geq 55$ \\
\hline \hline \multirow{2}{*}{ Household Income/ 10,000 } & $.0190^{* *}$ & $.0198^{*}$ & $.0164^{* *}$ & $.0406^{*}$ \\
\multirow{2}{*}{ Cardiovascular Disease } & $(.0115)$ & $(.0083)$ & $(.0098)$ & $(.018)$ \\
& $-.044^{*}$ & $-.077^{*}$ & $-.118^{*}$ & $-.0378^{* *}$ \\
& $(.021)$ & $(.020)$ & $(.029)$ & $(.018)$ \\
\hline \hline
\end{tabular}

Significance levels: * 0.01, ** 0.05. Standard errors, clustered by individual, are shown in the parentheses.

Other variables are: age, marital status, education, work status, chronic conditions, own house, urban location, and provinces.

Similar analyses were conducted on the basis of gender and age groups: male, female, age $<55$ and age $\geq 55$. The results of these regressions are shown in Table 3 . For all of these regressions, the coefficients for Cardiovascular Disease and Household Income are significant and they have the expected signs. The estimates of compensating 
income variation for these groups are shown in Table 4. It is found that females have higher CIV than males. ${ }^{6}$ This result contradicts the findings of Groot and Maassen van den Brink (2006). The results further show that the CIV for individuals age $<55$ is higher than that of individuals age $\geq 55$. This result is in conformity with the results which found that CIV declined with age.

Table 4. Estimated CIV by gender and age

\begin{tabular}{lc}
\hline Category & CIV \\
\hline \hline Male & $\$ 23,157$ \\
Female & $\$ 38,888$ \\
Age $<55$ & $\$ 71,951$ \\
Age $\geq 55$ & $\$ 9,310$ \\
\hline \hline
\end{tabular}

It is difficult to compare monetary valuation of cardiovascular disease across different countries because the psychological makeup of the peoples of different countries might be different. This study, using Canadian data, found that estimated CIV for cardiovascular disease for males was $\$ 23,157$ while the CIV for females was $\$ 38,888$. Using data from the British Household Panel Survey (1996-2000), Groot and Maassen van den Brink (2006) found that the average CIV for cardiovascular disease was GBP 49,564 for males and GBP 17,503 for females. Powdthavee and Bernard van den Berg (2011) used a methodology similar to Groot and Maassen van den Brink (2006) with the same British Household Panel Survey but with a different time frame (1996-2009). They found that the average CIV for Heart Disease/ Blood Pressure for the overall group (males and females together) was GBP 8000. On the other hand, this study found that the CIV for cardiovascular disease for the overall group was $\$ 33,701$.

\section{Conclusions}

The study estimated a well-being function to determine how much monetary value individuals assign for cardiovascular disease. To the best of the knowledge of the author, this is the first Canadian study to use a subjective well-being approach in valuing health losses due to cardiovascular disease. The study found that the calculated compensating income variation is $\$ 33,701$, suggesting that an individual is required to be paid this amount to compensate for the loss in well-being due to cardiovascular disease. The study further shows that the compensating income variation is higher for women than for men. The study also finds that CIV decreases with age.

The well-being approach for valuing health loss is a relatively new approach. There are two traditional methods to valuing health in monetary terms: revealed preference approach and contingent valuation approach. The revealed preference approach assesses the value of a health condition by looking at the amount of higher market wages that an individual requires for that health risk. A major drawback of this approach is that it is very difficult to obtain representative data (Powdthavee and Bernard van den Berg, 2011). The contingent valuation approach is a survey- based direct approach to elicit a subject's monetary valuation of health conditions. In this approach, the individual is asked how much he/she is willing to pay for reduction or elimination of particular health condition. Contingent valuation approach also has limitations, as individuals are usually confronted with hypothetical situations for which they have no personal experience. Consequently they may not fully comprehend the actual risks involved with

\footnotetext{
${ }^{6}$ Marginal disutility of health loss might be higher for females than for males.
} 
the situation (Maassen van den Brink, 2006). Furthermore, the results obtained from contingent valuation method depend on the format and framing of the question (Boyle et al., 2001; Johannesson and Borgquist, 1991). Compared to these two approaches, the well-being approach has a number of advantages. The well-being method only requires respondents to value their satisfaction in life and they are not asked to state a monetary value of the commodity under valuation (Van den Berg and Ferrer-i-Carbonell, 2007). Furthermore, the well-being valuation questions are relatively easy to answer and response rates for the well-being questions are quite high (Van Praag and Ferrer-iCarbonell, 2004). Finally, studies so far have not found evidence of framing or format effects in the well-being valuation approach (Van den Berg and Ferrer-i-Carbonell, 2007).

Future research may use data from other countries to validate the well-being approach. Further theoretical research is also needed to improve this relatively new approach.

Acknowledgements. I thank one anonymous referee for helpful comments. However, I am responsible for remaining errors.

\section{References}

Boyle, K.J., Holmes, T.P., Teisl, M.F. and Roe, B. (2001) A comparison of conjoint analysis response formats, American Journal of Agricultural Economics, 83, 441-454.

Clark, A.E, Frijters, P. and Shields, M.A. (2008) Relative income, happiness, and utility: an explanation for the Easterlin paradox and other puzzles, Journal of Economic Literature, 46(1), 95-144.

Ferrer-i-Carbonell, A. and Van Praag, B.M.S. (2002) The subjective costs of health losses due to chronic diseases. An alternative model for monetary appraisal, Health Economics, 11(8), 709-722.

Frey, B.S., Luechinger, S. and Stutzer, A. (2009) The life satisfaction approach valuing public goods: the case of terrorism, Public Choice, 138(3), 317-345.

Frey, B.S. and Stutzer, A. (2002) What can economists learn from happiness research?, Journal of Economic Literature, 46(2), 402-435.

Groot, W. and Maassen van den Brink, H. (2006) The compensating income variation of cardiovascular disease, Health Economics, 15(10), 1143-1148.

Johannesson, M. and Borgquist, L. (1991) Willingness to pay for antihypertensive therapy - results of a Swedish pilot study, Journal of Health Economics, 10, 461-473.

Luechinger, S. (2009) Valuing air quality using the life satisfaction approach, The Economic Journal, 119, 482-515.

Powdthavee, N. and Van Den Berg, B. (2011) Putting different price tags on the same health condition: Re-evaluating the well-being valuation approach, Journal of Health Economics, 30(5), 1032-1043.

Public Health Agency Canada (2009) Tracking heart disease and stroke in Canada, Catalogue No. HP32-3/2009E.

Statistics Canada (2010) Leading causes of death in Canada, Catalogue No. 84-215XWE.

Van Den Berg, B. and Ferrer-i-Carbonell, A. (2007) Monetary valuation of informal care: the well-being valuation method, Health Economics, 16(11), 1227-1244. 